\title{
A debate on Universal Morphology
}

\author{
Roberta D’Alessandro, Ángel J. Gallego, Alexandru Nicolae, \\ María Carme Parafita Couto, Diego Pescarini, Anna Pineda, \\ Michelle Sheehan
}

This debate stems from Michal Starke's keynote lecture at NELS 51, entitled "UM. Universal Morphology". The video can be found at this link: https://michal.starke.ch/talks/2020-11_nels/nels_starke.mp4.

In his talk, Starke sketches a nanosyntactic analysis of French irregular verbs, with the aim of showing that irregularities in French verbal paradigms (and in general) are only apparent.

We asked some prominent morphologists and morpho-syntacticians to comment on and provide replies to Starke's proposal and arguments. Subsequently, the author wrote a reply to these comments. You can find them all here.

We wish to thank the NELS 51 organizing committee for allowing us to use the talk as a starting point for the debate, Michal Starke for his availability, and the linguists who agreed to engage in this interesting and fruitful exchange.

This keynote debate celebrates the first year of the new Isogloss, in the hope of having more occasions to host discussions like this one. 